\title{
HISTORICAL, PROCEDURAL AND PEDAGOGICAL ASPECTS OF SOCIOLINGUISTICS
}

\section{GERALD L. DENNING}

\author{
University of Kansas
}

A brief presentation is made concerning historical aspects of the development of sociolinguistics. Certain concepts and procedures used in data analysis are described and exemplified. And the application of sociolinguistics to pedagogy is discussed.

When a student of language needs to ask sociological questions about data, he is fortunate that the groundwork has been laid for this type of interdisciplinary research. Less than a generation ago, most invitations and suggestions for mutual involvement of sociologist and linguist remained unfulfilled. For example, in 1946, Raven McDavid, a dialectologist, lamented the fact that professionals in other social sciences were not making sufficient use of the increasing amount of linguistic data elicited by fieldworkers. And he pointed out that the study of the speech of a given community could reveal various factors concerning its social composition, e.g., urban vs. rural population and social class distribution (McDavid, 1946).

By 1956, Glenna Pickford, a sociologist, held that sharing linguistic data would be profitable if the linguist took it upon himself to utilize the research methods of other social sciences in order to show not only what is said (actual utterances, with accompanying linguistic descriptions at various levels of grammar: phonological, syntactic, semantic, stylisticl, but which social factors have conditioned what is said (the social environments of the utterances). She further implied that the linguistic reality of an utterance should be viewed properly as part of a larger social reality and stated that additional variables would necessarily have to be contended with besides those traditionally favored by the linguist, such as the age, education, occupation, geographic location, and native language of informants. In particular, Pickford stated that subdivisions of variables were possible, e.g., social class, and that these, in combinations, could be relevant for sociological identifications of linguistic data. For example, she mentioned that attitudinal patterns of informants as well as narrow delimitations of socio-economic levels and occupations could help supply specifications requisite to sociological analyses for the purpose of attaining an adequate definition of the concept of social class (Pickford, 1956).

The need of sociology for linguistics was recognized, since it appeared to offer a worthwhile method of marking social distinctions (Pickford, 1956). And the need of linguistics for sociology has likewise been acknowledged (Hymes, 1966).

Growing mutual interest by linguist and sociologist has resulted in the development of a new interdisciplinary area: sociolinguistics. Both disciplines have shared the hope that reciprocal benefits would accrue, such as, for the sociologist, the role of language as a social behavior, and perhaps, because of its infinite capacity for variation, as the best reflection or measure of its social content, and for the linguist, how grammatical systems operate in more precisely specified social 
situations, and ultimately, what is the nature of language. However, this is not to say that sociolinguistics would be subservient to either of the parent fields, but rather that theoretical sociolinguistics is capable of maintaining a separation from them (Hymes, 1966).

A Weltanschauung of language unique to sociolinguistics has been voiced by Hymes which manifests a distinctness from linguistics proper: "Descriptive sociolinguistics in the modern world is inseparable from encounter with social change. Indeed, for a systematic theory to emerge, many phenomena now treated as diverse types-acculturation, bilingualism, creolization, linguistic nationalism, pidginization, standardization, construction of artificial languages, vernacular education-must be seen as interrelated within the history of European expansion and the emergence of a world history" (1967: 645). Linguistics is under no constraint to consider social determination of speech. In fact, efforts to isolate linguistic universals regardless of racial, cultural, societal and linguistic diversity around the world attest to this (Gumperz and Hymes, 1972: vii).

If the sociologist finds in a particular study that the use of a linguistic variable, e.g., a phonological or grammatical element of a language, is non-indicative of social values, he will discard it in favor of other types of variables. A truly sociolinguistic approach, however, is interested in the relation of linguistic variables to group membership for its own sake. If linguistic variables are not significant indicators of group membership in a given case, sociolinguistic theory will be interested precisely because such a case may help disclose the circumstances in which features of a language do and do not function (Hymes, 1967).

William Labov has provided impetus for significant interest in sociolinguistics through his contributions, such as "Social Motivation of a Sound Change." In that study he examined the centralization of phonetic variants of the first element of the diphthongs /ar/, /av/ by native speakers on Martha's Vineyard in light of historical and current linguistic and socioeconomic factors. "He found that those who planned to remain on the island maintained usage of the centralized diphthongs, as a way to preserve their identity (especially against numerous summer-dwellers and tourists) while those who planned to move to the mainland adopted the Standard uncentralized varieties" (Labov, 1963).

Labov has further enriched sociolinguistics with his concept of variable rule, which theoretically could replace a former concept: free variation (Labov, 1968:24). Rather than refer to a pair, or a group of grammatical or phonological elements as free variants, that is, which vary for no apparent reason, e.g., long vs. short $e$ as the first vowel in economics, he preferred to attempt to formulate variable rules, including linguistic and non-linguistic constraints, in order to explain variances. Linguistic constraints (factors which prevent a rule in a language from having full coverage) apply at any level of grammar. Examples of phonological, semantic and social constraints will follow.

One can state as a phonological rule of English that the sound ending sing, ng, never occurs word-initially. Let us suppose, however, that this sound began to occur around the country, and that linguistic analysis showed that when it occurred it always preceded a back vowel, e.g., $u, o$. Thus, a phonological constraint may be added to the rule, so that it would read: $n g$ does not appear word-initially except before a back vowel. Yet most of the time $n$, not $n g$, is used in this phonological environment. The linguist, in this hypothetical case, can specify a phonological constraint for instances when ng occurs, but may attribute cases when it doesn't to free variation. A sociolinguist who extends the analysis might feel that at least three social constraints co-occur with the phonological one, which would condition the rule further: $n$ changes to $n g$ 
before back vowels during a formal conversation between persons of different educational levels when the more educated person uses it first.

The next example, which identifies a semantic constraint of a syntactic rule, has been drawn from data collected by the writer in a preliminary study of Spanish passive constructions used by middle-aged Lawrence, Kansas Chicanos. Informants were presented with English utterances, e.g., (1), (3) for Spanish paraphrase. Such utterances in Standard Spanish are normally rendered into passive voice, traditionally called true passive, which is composed of a form of ser 'be' plus a past participle denoting action by an agent that is clearly implied if not stated (Tarr-Centeno, 1961: 199-121).

(1) The house was built by three persons.

(2) La casa fue construi'da por tres personas.

(3) The dish was broken by the dog.

(4) El plato lo quebró el perro.

Elicitations separated informants into several groups, one of which at times used the passive, see (2), but at other times used topicalization, a related structure involving fronting of the active direct object (where in a passive construction it would be subject) but maintaining active voice, cf., (4). Additional questioning of the informants' intuitions revealed that for passive use in (4) the agent had to be human. In this case, the syntactic rule describing the passive construction and its use would carry, besides agent, the two prerequisite semantic features: [+ animate], [+ human] which constrain it.

Anyone doing sociolinguistic research must work with linguistic data. Sociolinguistic techniques of gathering data and procedures for analyzing it are numerous. It would be wrong to assume that one method would work equally well in all sociolinguistic problems. The diversity and number of variables which occur at various levels of grammar in a speech sample, the introduction of societal influences affecting it, such as speaker roles, social situations, cultural values, and how much or how deeply one wants to investigate, preclude such a view (Fishman, 1971: 54-56). One might find it feasible to collect written vs. spoken data for a particular study, e.g., writing stylistics. If a spoken sample of casual speech is required, a formally conducted interview would most probably serve less effectively than an informally conducted one, or a free conversation at an appointed time and place, or even a spontaneous street encounter. Speech samples can be jotted down in phonetic symbols or recorded on magnetic tape. When the latter technique is used, sound fidelity necessary for the subject matter dictates the quality requirements of the apparatus.

After the data has been assembled, and a variance, e.g., between a standard language form and a dialectal form, or between dialectal forms, has been noticed, one may want to take a linguistic stance, and if this fails to lead to a solution, to proceed on a sociolinguistic basis. Two manners of viewing linguistic variations apparent in data will be discussed: internal linguistic change and sociolinguistic interference.

In studying a historical problem, such as why a number of Old English case markers of the definite article (Modern English the) have been lost in speech, one might utilize the concept of internal linguistic change, i.e., simplification of certain grammatical forms, perhaps by analogy to other forms so that a more symmetrical linguistic pattern resulted. A linguistic state of constant readjustments would explain the diachronic flux. This is treated by Sapir (1921: 147-170). 
On the other hand one might posit that a non-English society came into contact with the speakers of Old English because of migrations or wars, and that the temporary presence and use of another grammatical system caused change to occur in the definite article. This process of change could have been advanced by bilinguals who mixed the two language systems in certain ways so that hybrid forms resulted, among them a caseless definite article. The same change might have resulted from interference of another variety of Old English rather than of a foreign tongue. Perhaps speakers of such a dialect played important roles in society with the effect that many speakers adjusted their definite article production toward that of the prestigious speakers.

A number of linguists and sociolinguists believe that historical problems involving human speech can be examined best from the perspective of synchronic analyses. Therefore, the question of the development of the English definite article into its present shape possibly should be deferred until similar changes are observed and examined in other case markings of other languages, perhaps ideally of other genetically related, i.e., Germanic, languages.

It is a fact that phonological distinctions which mark specific cases of the Standard German definite article are not present in certain other varieties of High German spoken today. For example, in a pilot study of definite article usage by Volga German bilinguals of Western Kansas, the writer obtained data indicative of possible phonological leveling between the masculine singular dative and accusative forms. The Standard German dative dem in utterances such as (5) was given the shape den, cf. (6), when rendered into Volga German. Both varieties use den as the accusative form. (7) provides an English equivalent.

(5) Vor dem Krieg hab' ich an America nicht gedacht.

(6) Vor den Krieg han ich an America gar net gedendt.

(7) Before the war I didn't think about America.

In a strictly synchronic analysis there is no room to speculate that Volga German dative den had ever been anything else phonologically. Rather, diachronic studies would have to be undertaken to try and identify earlier samples of Volga German which might have additional case markers. However, synchronic sociolinguistic studies might be able to shed light upon the question of possible recent change, if not change in progress, in the shape of the Volga German masculine singular dative definite article.

Similar phenomena have been observed in other varieties of High German (and Low German, which shares a closer genetic link to English). For example, various High German varieties do not exhibit a phonological genitive case marker. In some Swiss German varieties possible phonological change has resulted in accusatives taking the same form as nominatives and in certain Low German varieties both dative and accusative phonological distinctions appear to be absent (Werner Winter, 1973: personal correspondence).

Again, the concepts of internal change and interference may be employed, but not without difficulties. Interference may be posited in the case of Volga German bilinguals, since monolingual English speakers in daily contact with them model the uniform English definite article. However, no such argument could be advanced for varieties in Germany. Internal linguistic change could be viewed as the reason for the absence of phonological case markers in many dialectal varieties, which could mean that they are developing at a faster rate than the standard variety. This would predict that similar changes should 
become observable in Standard German in the future. At this point justifications for further use of the concept internal linguistic change would retain internality only insofar as possible changes occurred in a given variety with no interference from external linguistic systems. However, social causes which could be brought to bear on the questions, if the discussion were to continue, would constitute externality in that they are essentially non-grammatical. This seems to offer a plausible rationale for expanding, rather than ignoring, the original concept of internal linguistic change.

In the case at hand, observation of the use of phonologically distinct dative and accusative forms in one generation of speakers and non-distinct forms in a following generation, would comprise social information relevant to sound change. If such an ideal solution were not forthcoming, perhaps the complex of societal influences possibly causing speakers of a standard variety of speech to resist sound differences observed among speakers of non-standard varieties should be investigated further.

The existence of varieties of speech, and the concomitant linguistic and sociolinguistic description of their compostion and raison d'etre, puts these disciplines in a position to aid the area of language pedagogy in the design and content of the usual native and second language courses, and also in the formation of the more specialized teaching materials to be used in bilingual and dialectal situations. One might refer to the latter application as applied sociolinguistics.

Two linguistic concepts are relevant to a discussion of the pedagogical application of sociolinguistic facts: linguistic competence (complete knowledge of his own grammar at each level, which a native speaker of any variety of speech has), and linguistic performance (speech production). The sociolinguist, by virtue of his understanding of competence underlying speech and his interest in social factors influencing performance, has already begun to affect the views of educators of social dialect speakers. However, there are theoretical and practical differences of opinion between some sociolinguists and educators.

At the theoretical level, Siegfried Englemann, an educational psychologist, has opined that professionals of a linguistic persuasion should be concerned only with competence, and leave performance to psychologists and perhaps instructors (Englemann, 1971). This position seems untenable in view of the relationship between competence and performance, and especially because significant contributions have already been made by sociolinguists in the area of contention: see Labov's "The Logic of Nonstandard English" (1970).

At the practical level the sociolinguist cannot share certain views of the educator, in particular the notion that speakers of nonstandard varieties of language are somehow linguistically deficient and need to be retrained in "correct" speech forms (Cazden, 1971; Wolfram, 1971).

One holding such a view is again escalating to the theoretical level and has entered the area of competence, which the linguist has shown to contain for each speaker a complete grammar capable of generating correct utterances in his own variety of speech. There is no linguistically superior variety of any language, since all varieties of all languages are equally expandable and contractable according to need (Fishman, 1970: 24). What is required at this point in the discussion are not linguistically-based (in a structural sense only, such as content analysis) novel methods of teaching standard forms while ignoring the student's own forms, but rather an evaluation of justifications for pedagogical ends. "The entire issue of teaching Standard English to speakers of social dialects is in need of meaningful rationales if new approaches are to be developed" 
(Kernan, 1971: 67). After all, dialects are mutally intelligible and a uniform writing system could serve all varieties. The occurrence of and value in the process of standardization of a variety of a language is not disputed (Fishman, 1970: 24). Rather, how much of it is necessary or useful is being questioned. Is it really important that a lower-class black child include an overt copula, e.g., is in He sick if the expression means the same thing without it?

Concerning bilingualism, a speaker's competence in either of his languages increases or decreases with respect to need, i.e., to what degree a language must be used in the roles he plays in various social contexts. In the bilingual, a relationship of the two language systems theoretically could be established to any degree on a scale running from coalescence to separation (Haugen, 1972: 317). Bilingualism perhaps gives the most extreme examples of linguistic capacity for change.

This property of language for constant adjustment applies to all varieties. Therefore a standard variety of any language may be viewed as a linguistic system ready to change to a somewhat different system. In this sense, all varieties of a language may be considered to be intermediate systems. "The standard is itself only an intermediate system which has been temporarily frozen by social or academic fiat" (Haugen, 1972: 323).

This view of a standard variety of a language could perhaps lead to a new outlook on nonstandard varieties. Far from being obstacles in the classroom, these varieties are actually already bridges extending to the standard. There may be no more need to get off a bridge than to attempt to destroy its bridgework (Haugen, 1972: 322).

In this way pedagogical endeavors can be based on a humanistic point of view (Samarin, 1971: 140). A very important aspect of the social identity of the person being educated is touched: his language. It may be that doing as little violence to it as possible is the ideal classroom approach from a humanistic point of view.

\section{References}

Cazden, Courtney

1971 "Approaches to social dialects in early childhood education." Pp. 70-81 in Roger W. Shuy (ed.), Sociolinguistics: a Crossdisciplinary Perspective. Washington, D. C.: Center for Applied Linguistics.

Chomsky, Noam

1965 Aspects of the Theory of Syntax. Cambridge, Mass.: The M.I.T. Press.

Englemann, Siegfried

1971 "The inadequacies of the linguistic approach in teaching situations." Pp. 141-151 in Roger W. Shuy (ed.), Sociolinguistics: a Crossdisciplinary Perspective. Washington, D. C.: Center for Applied Linguistics.

Ervin-Tripp, Susan M.

1971 "Social dialects in developmental sociolinguistics." Pp. 35-64 in Roger W. Shuy (ed.), Sociolinguistics: a Crossdisciplinary Perspective. Washington, D. C.: Center for Applied Linguistics.

Fishman, Joshua A.

1970 Sociolinguistics: a Brief Intruduction. Rowley, Mass.: Newbury House Publishers.

1972 Language in Sociocultural Change. Essays selected by Answar S. Dil. Stanford: Stanford University Press. 
Fishman, Joshua A. (ed.)

1968 Readings in the Sociology of Language. The Hague: Mouton.

Fishman, Joshua A., Robert L. Cooper and Roxana Ma

1971 Bilingualism in the Barrio. Bloomington: Indiana University.

Gilbert, Glenn G. (ed.)

1970 Texas Studies in Bilingualism. Berlin: Walter de Gruyter.

Gumperz, John J. and Dell Hymes (eds.)

1972 Directions in Sociolinguistics: the Ethnography of Communication. New York: Holt, Rinehart and Winston.

Haugen, Einar

1953 The Norwegian Language in America: a Study in Bilingual Behavior. 2 vols. Philadelphia: University of Pennsylvania Press.

1972 "The stigmata of bilingualism." In The Ecology of Language. Essays by Einar Haugen selected by Anwar S. Dil. Stanford: Stanford University Press.

Houston, Susan

1970 "A reexamination of some assumptions about the language of the disadvantaged child." Child Development 41 : 947-963.

Hymes, Dell

1964 Language in Culture and Society. New York: Harper \& Row.

1967 "Why linguistics needs the sociologist." Social Research 34: 632-647.

Kernan, Claudia Mitchell

1971 "Response" to "Social dialects in developmental sociolinguistics," by Susan M. Ervin-Tripp. Pp. 65-69 in Roger W. Shuy (ed.), Sociolinguistics: a Crossdisciplinary Perspective. Washington, D. C.: Center for Applied Linguistics.

Labov, William

1963 "Social motivation of a sound change." Word 19: 273-309.

1965 On the Mechanism of Linguistic Change. James E. Alatis (ed.), Georgetown University Monograph Series on Languages and Linguistics 18: 91-114. Washington, D.C.: Georgetown University Press.

1966 The Social Stratification of English in New York City. Washington, D. C.: Center for Applied Linguistics.

1970 The Logic of Nonstandard English. James E. Alatis (ed.), Georgetown University Monograph Series on Languages and Linguistics 22: 1-43. Washington, D. C.: Georgetown University Press.

Labov, William, Paul Cohen, Clarence Robins and John Lewis

1968 A Study of the Nonstandard English of Negro and Puerto Rican Speakers in New York City. Final Report. Cooperative Research Project 3288, Office of Education. 
McDavid, Raven I., Jr.

1946 "Dialect geography and social science problems." Social Forces 25: 168-172.

Pickford, Glenna R.

1956 "American linguistic geography: a sociological appraisal." Word 12: 211-233.

Perlmutter, David M.

1971 Deep and Surface Structure Constraints in Syntax. New York: Holt, Rinehart and Winston.

Samarin, William J.

1971 "Response"to "Social dialects from a linguistic perspective," by Walt Wolfram. Pp. 136-140 in Roger W. Shuy (ed.), Sociolinguistics: a Crossdisciplinary Perspective. Washington, D. C.: Center for Applied Linguistics.

Sapir, Edward

1921 "Language as a historical product: drift." Pp. 147-170 in Language. New York: Harcourt, Brace \& Wrold.

Tarr, F. Courtney and Augusto Centeno

1961 A Graded Spanish Review with Composition. New York: Appleton-Century-Crofts, 119-125.

Weinreich, Uriel

1953 Languages in Contact: Findings and Problems. New York: Columbia University.

Winter, Werner

1973 Personal correspondence.

Wolfram, Walt

1971 "Social dialects from a linguistic perspective." Pp. 86-135 in Roger W. Shuy (ed.), Sociolinguistics: a Crossdisciplinary Perspective. Washington, D. C.: Center for Applied Linguistics. 